\title{
National Security and Good Governance: Dynamics and Challenges
}

\author{
Prof. Dr. Razia Musarrat \\ Chairperson, Department of Political Science, The Islamia University of Bahawalpur \\ Email: drrazia_mussarat@yahoo.com
}

Rehman Afzal

Lecturer, Government Degree College for Special Education, Bahawalpur

Muhammad Salman Azhar

Lecturer, Department of Management Sciences, The Islamia University of Bahawalpur

Received: January 08, 2013 Accepted: February 02, 2013 DOI: 10.5296/jpag.v3i1.3525

\begin{abstract}
Post cold war era has different implications for all the sectors affecting human development and survival. A new approach has emerged that analyses these issues from the perspective of human development rather than state opportunities. This paper is an attempt to examine the changing dynamics of national security for Pakistan and to analyze the critical relationship and impact of good governance over national security in the wake of $21^{\text {st }}$ century requirements. This paper presents an outline of issues and their underlying factors of good governance and explains the impact they have over defining and achieving national security goals. Concepts of both good governance and national security are revisited to frame guidelines for future implementation.
\end{abstract}

Keywords: National Security, Governance, Good Governance, Human Security 


\section{Introduction}

Post-Cold war era has certain distinct characteristics in the context of security of states that had new dynamics. In terms of foreign policy in the post-cold war era, interdependence driven by globalization was the key factor. Cold war security paradigms were no longer acceptable to the majority of nations. Nongovernmental, non-state and multinational entities emerged as factors of change in the political, economic, social and military security agenda. This interdependence between states is complicated in nature because it does not rely on strict ideological loyalties like in the period of cold war. New inter-state agenda carried motivations of economy and regional dominance as a driving force for interstate alliances. State structures can also be stated in terms of politico-economic institutions that form a framework for internal and external actors (Lindberg, 2001:175).

It would be appropriate to point out the fact that issues that come to the forefront in the post-cold war era were not new. Issues like terrorism, drug trafficking, money laundering were existed long before cold war. My focus here is to highlight the changing dynamics of human society in the post-cold war era that have served as a basis of major change in the state priorities in terms of national security. Understanding of issues like health and population have now different dynamics and priorities then in cold war era. This is not limited to any particular aspect of human society. Dynamics of conflict and peace, interaction and diplomacy etc have now different implications for human society. To understand this fact is the key to understand the changing dynamics and inter-relationship between different entities such as national security and good governance. It is argued that collapse of communism has also resulted in so called peace dividend (Andrew \& Goldsmith, 1998: 103).

New and emerging paradigm for understanding global and state vulnerabilities that have been challenged by $21^{\text {st }}$ century is the paradigm of Human Security. The critical shift from state to human security is the key to our study. This paradigm challenge the traditional notion of national security by arguing that referent object for security is now individual rather than the state. The concept of human security that is the corner stone of new national, regional and global agenda is emerged during post-cold war period. Many fields, including development studies, international relations, strategic studies, and human rights have contributed in the development of human security. Human Development Report in 1994 by United Nations Development Programme is considered a milestone in the field of human security. Having said that, some argue that the list of elements of human security is so long that it seems very difficult to exclude anything from the concept (Paris, 2001: 90).

Critics of the Human Security argue that its effectiveness is undermined by its vagueness and therefore it does not help to the extent that is required for researchers to understand and find solutions for certain issues. Consequently, it does not help research community to frame and formulate good policies in the context of security. It is however argued that sovereignty lies at the heart of democratization (Lindberg, 2001:177).

Seven distinct areas of global security as promoted by human security paradigm should be highlighted here for my study as these areas are directly related to good governance and national security. First is Economic security that basically assures basic income for 
individuals is secure, second is Food security that assures physical and economic access to basic food, third is Health security that aims to guarantee minimum required protection from diseases and unhealthy lifestyles, fourth is Environmental security that aims to protect people from the degradation of natural environment, fifth is personal security that provides assurance of protection from physical violence, sixth is Community security that protects people from loss of relationships and values from sectarian and ethnic violence, seventh is Political security that assures protection from systematic political repression and human rights violations. Global insecurity on the other hand can be answered through discursive democracy (Dryzek, 2006).

\section{Scope and organization of Study}

The scope of this study is limited to interrelationship of national security and good governance. Impact and dynamics of good governance for analytical study sets the basic context of this study. Key characteristics of national security as well as good governance is explored in detail. $21^{\text {st }}$ century offers different perspective about designs of national security that is responsive to the on ground realities of a state. This study does not discuss governance during cold war and does not focus the traditional international relations philosophies such as realism, idealism and liberalism etc rather it focuses on nontraditional philosophies and paradigms that were emerged after the end of cold war. Changing dynamics of national security in post 9/11 era are of special importance for this study.

Pakistan has been selected as a case study for analysis because it provides us unique opportunity to analyze the new and critical relationship between national security and good governance in the context of a country that is the main battleground of war against terror; its population is the victim of terrorist attacks on regular basis. It is a nuclear capable state with known nuclear proliferation issues. It has weak political institutions and economic condition that is a constant focus of international concern and it is a state which is going through a whole array of crises i.e. security, economy, identity and democracy.

This study is organized in such a way that it analyses the dynamics of National Security and Good Governance and their interrelationship in first place and then it broadens the scope of analysis to specific issues of good governance in Pakistan. Dynamics of Pakistan's National Security in the context of $21^{\text {st }}$ century perspective and its implications are explored and finally Good Governance and National Security challenges for Pakistan are analyzed.

\section{National Security and Good Governance: Dynamics of inter-relationship}

The concept of good governance is ages old rather it is as old as civilization itself. History reveals that empires destroyed, states broken up regimes vanished because of bad governance. This implies clearly that good governance is the key ability of a government to maintain control over a state. Terrible consequences of bad governance can be seen in the recent history. Governance, therefore, in my view, is an obligation not a choice for any elected and true representative political government of present day. Good governance should, and it must result in decision making that is fruitful and beneficial for the masses and through which they feel secure and participative as if they themselves would have made those decisions.

That leads us to the next part of our discussion that is relevant to security. In a broad sense, 
security is comprised of three basic factors, traditional security in a militarized sense, human security that comes from economic progress and good governance and finally the rule of law. These three determinants of security are critical to our discussion. Having said that, it is imperative to note here that prime responsibility of a state is security. Understanding security in totality is important.

Words "security" and "threat" are cognate words. It is however necessary for any useful discussion on security or threat that the entire scenario should be taken into consideration. All strategies have their consequences and security scenarios are of no exception to this fact. Source of insecurity should carefully be analyzed to determine the focal points of national security strategy for any state. I want to emphasize the complexities of a responsive national security policy and its multifaceted nature. Further, security is not a standalone concept and especially it cannot be separated from governance. It is important to note here that governance is not limited to development rather it encompasses all the sectors of human society that ensure quality of life for a human being. Traditionally, security has been considered as physical means of protecting sovereignty of a state but in Westphalian model, security is constructed parallel to the protection of social order (Bislev, 2004: 282).

Link between security and good governance is vital since good governance helps prevent conflict and therefore it ensures peace and prosperity. The link that I have pointed out is more clearly explained by Kant two centuries ago when he said, "People who feel secure and free, governed by the rule of law and not of men, are much less likely to go to war with each other - either within or across borders - than those who don't'. it is self explanatory that if government is responsive to the requirements of its people and is properly and justly utilizing resources whatever available to the benefit of its population will strengthen its bond with people and will lead to a strong internal structure that will help promote and sustain a national security policy based on consensus and support of the masses. If not this condition, bad governance will lead to insecurity that will lead to instability and that would certainly affect national security of a country negatively.

It is an open secret that improvements in good governance are directly linked to security and stability. Further, erosion of democratic vitality can be the logical outcome of complexity and sizing problem of democratic institutions on ground (Fung \& Wright, 2001: 6). If governance strategy of a particular government is the consolidation of political structures and the establishment of legitimate democratic institutions, power-sharing and promotion of human rights along with provision of such free and dynamic environment that is friendly for development and is corruption free then peace and prosperity will prevail.

\section{Good governance in Pakistan: An Analysis}

The ultimate challenge and goal for all societies has been the creation of a system of governance that is conducive to human development, just and more supportive to the poorest. In one understanding, governance can be defined as the exercise of economic, political and administrative authority to manage a country's affairs. It includes development and implementation of mechanisms, processes and institutions through which citizens and groups articulate their interests, exercise their legal rights, meet their obligations and mediate their 
differences. Good governance is extension of governance concept and that means governance that is efficient, participative, transparent and accountable. There are three main dimensions of governance, economic governance, political governance and administrative governance. I shall use these three dimensions for analyzing good governance in Pakistan.

It can be safely argued that since last decade or so, good governance has emerged at the forefront of the development agenda in Pakistan. All the entities that matter in the modern and globalized world that include but not limited to masses, corporate enterprises and investors both domestic and foreign see good governance as the key ingredient for the creation and development of an environment that is investment friendly and could sustain the development. Further, finance that is the key for development cannot be attracted today through a system that is closed and more importantly non-transparent. A transparent system that is comprised of simple but effective and time efficient procedures is a basic pre-requisite for good governance. It can therefore be argued that the age we are living in today is the age of transparency. Good governance does not limited to the delivery of financial services but it surly influences other sectors of society equally that results in a culture that promotes and encourages transparency and discourages corruption.

Briefly, the political system of Pakistan has been broken down so many times. This has caused weakening of political order and emergence of non-viable political institutions and processes that have favored entry of military bureaucratic elite, military rule and military dominated civilian governments, and authoritarian and narrow-based power management. A quick look at Pakistan's political history reveals that different phases of Pakistan's political history with reference to the dominant style of governance and political management are civilian political government, direct military rule, and various so-called democratic designs promoted by military rulers. Briefly, Pakistan could never escaped the legacy of its colonial past (Ziring, 2007: 609).

Above historic overview presents various pitfalls to good governance in different political eras. Wherever there was any favourable economic condition, it was a direct result of reforms that were initiated and they triggered an investment friendly environment. However, lack of political stability resulted in either premature termination of planned reforms or change of priorities to the extent that the net effective result was compromised. This however, implies that reforms lie at the core of our economic turnaround and once initiated needs continuation. Having said that, we must never forget that re-alignment and efficiency and delivery audits of such reforms are of critical importance to ensure that they are delivering those benefits to the people for which they are being formulated and introduced. Achievement of growth is one thing and to sustain this growth requires a committed approach because the ultimate goal of good governance is sustainable economic growth that delivers social and economic goods to the masses. Resultantly, it can be argued that the concept of good governance relates to the quality of the relationship between government and its citizens because of whom it exists and to whom it is bound to serve and protect.

For the sake of analysis, the key characteristics of good governance are comprised of participation, rule of law, transparency, responsiveness, equity, effectiveness and efficiency and accountability that is supported by a strategic vision. It is important to note here that all 
these core characteristics are interrelated and do not work as standalone entities. They are all mutually reinforcing. I shall now focus on governance in Pakistan since its independence and will briefly outline the key characteristics of governance that has prevailed on ground in Pakistan.

It can be observed that there is a fundamental flaw in Pakistan's political system and that is the absence of democracy. Feudal class is the most successful class in Pakistan's political system that has served as a dominant social base from where majority of our politicians emerge. Middle class or working class is not represented in politics as it should be and their participation is almost non-existent. To my analysis, this flaw is not a minor one. It has serious implications for politics and governance. First of all this raise the question about legitimacy of decision making. The whole concept of "Government of the People, for the people and by the people" is undermined.

Having said that, I don't believe that emergence of middle class alone on the horizon of politics can solve all of our problems and can introduce sustainable democratic governance. In fact, political institutions are only one dimension of governance and not all. What is required is the building of competence through good governance education for members of democratic institutions such as the executive, the legislature and the judiciary. All three pillars of state should and they must play their part in ensuring good governance.

It is a fact that education sector has never been on its feet to provide solid and sustainable support to the governance system. If analyzed in deep, the dominance of civil and military elite has one common factor. At the time of independence, both civil and military had established institutions for professional training along with British professional legacies that have played a vital role in establishing their dominance over ordinary educated Pakistani that was not entered in these two spheres. Unfortunately, the legacy continues.

The good governance failure is compounded by the fact that the irrespective of the fact that from what class politicians emerge, they do not have any such training to serve at the highest positions of leadership and executives. In what way than, they can be expected to deliver. It is highlighted by almost every one that parliament is the law making body and is supreme. My question here is that how and in what capacity poorly educated, untrained and uninformed politicians can make laws that are key to good governance. The whole concept of governance is then questionable and good governance is logically not possible.

Public service delivery is a key area of good governance. In Pakistan's context a range of indigenous factors and practices can be observed that affect the delivery of public service effectively. I shall just outline some important points of civil services sector. These are common but have affected civil service servants badly. These include transfer of bureaucracy frequently against the established norms of duration of service at one particular place of posting, support / abuse of different political groups, lack of incentives that often results in exit from public service due to frustration, transparent accountability mechanisms that affect loyalty of honest workers directly etc.

Summing up, good governance in Pakistan has never been an area of strength rather it has been subject of political decay that has affected governance badly. This has resulted directly 
in spread of corruption, mismanagement, against the merit recruitment and broadly speaking failure to deliver the goods to the masses. This governance scenario is not standalone as described earlier. It has logically affected national security that I shall examine now.

\section{Dynamics of Pakistan's National Security: $21^{\text {st }}$ century perspective}

As apprised earlier in my paper, we are living in an era that has entirely different implications of security then it was during cold war or earlier. Post 9/11 period has introduced more complications to this fact. The question of whether a country is secure or vulnerable is not a simple one. Threat is multifaceted and not limited to military. It might be that a country is not faced by conventional military threat on its territory or by any hostile power but its openness due to technological globalization and internationalization in more than ever interconnected world can be a serious threat to its social, political, economic and even military entities. It can therefore be argued that in today's dynamic world a country can very well be secure and vulnerable at the same time.

Leaving aside the brutal past and certainties of cold war where the danger had a face that was existential, today Pakistan faces a different and more complex range of threats, both internal and external. Terrorism, extremism, cyber attack, unconventional attacks, insurgency, sectarian violence, trade deficits, heavy external lending through international financial agencies, under-development, lack of foreign direct investment, physical insecurity, corruption, health and education sector degradation, inflation, unemployment, brain drain, bio hazards, water, food and energy security crisis as well as large scale accidents and natural disasters like earthquakes and devastating floods are major threats faced by Pakistan's national security today.

I have intentionally listed so many threats. my aim was to highlight the fact that this list gives us a very clear idea that first most of new threats are internal rather than external and secondly their majority is directly or indirectly related to governance. The characteristics and dimensions of governance that we have discussed earlier can very well be analyzed in the context of these threats I have just mentioned. This clearly defines the relationship and impact that good governance has to the national security of Pakistan.

These threats can be emanated from states as well as non-state actors: criminals and terrorists funded and supported by domestic or overseas entities. Our security is also vulnerable because of effects of climate change and its impact on food and water security. Therefore, the concept of national security in 2012 is very different to what it was ten or twenty, let alone sixty four years ago when Pakistan came into being. Geographically Pakistan is a small country but at the same time located at such an ideal strategic location that this location has made Pakistan vulnerable to all major world powers interference and also has provided an excellent opportunity to translate this strategic location to its national advantage and secure its resources for prosperity.

Having said that, this requires peace at home and good governance because it is the internal strength that provides external strength. No country can stand and face all these threats when it is weak from inside. In our case, unfortunately, we are weak and vulnerable to all of these threats in terms of internal security. let me clear here that military superiority or nuclear 
weapons technology can never strengthen a country, it has never been. The example of USSR is vital to learn from. It is the internal strength that provides solid foundation for strength and it can only be developed through good governance. Now I shall focus on the major challenges faced by good governance and national security of Pakistan in the context of future.

\section{Good Governance and National Security: challenges and priorities}

Briefly, following are the major and immediate challenges for Pakistan to address in the context of good governance.

1. Rule of law

2. Corruption

\section{Accountability}

4. Lack of democratic practices

5. Weak state institutions

6. Effective parliament

7. Transparency

8. Devolution of power/ effective and responsive local government system

9. Visible Separation of powers

In the age of uncertainty, where Pakistan is faced with complex and multifaceted threats, a radical transformation in national security strategy is required so that national interests could be protected. Having said that, making strategy is one thing and implementing it successfully and yielding desired results is another. In my view, no national security strategy would work in the absence of a responsive good governance based government in power. Future can have unexpected demands from Pakistan's security apparatus as it had for many major powers in the recent past. The strength required for this unforeseen task can only be sustained through good governance to our people who actually makes our nation.

Twelve years have now elapsed since the world changed almost beyond recognition. World around us have changed so much. Unfortunately, Governments in Pakistan have failed to adapt to the new circumstances. Their planning lacks both the seriousness and urgency and the integration needed to cope with the new situation. Previous experience of continuous conflict between democratic values and authoritarianism, failure to introduce sustainable institutional development need to change to counter new threats.

The biggest challenge for Pakistan now is to overcome and decrease the distrust and alienation of common person from the political process and system. Same is valid for security establishment. A growing popular perception in Pakistan that is most dangerous to any political system is the feeling that their vote does not count and the government in power is irrelevant to their problems. Such disconnect can be destructive for any political system and needs to be addressed on war footings. However, this can only be overcome through effective governance that can deliver the social and economic goods and make people interested in political system. Participation of people of Pakistan is the key for any political and national 
security strategy to succeed.

\section{Conclusion}

In an age like we are living in today requires a quick and effective response to deal with the emerging new threats faced by Pakistan's national security. in other words that means right people should do the right jobs at the right time. Foreign and domestic security concerns are not separate. Both are dealt by same leadership and same nation. It might be the reality that Pakistan has not inherited a well-defined and supportive defense and security infrastructure backed by a strong economy but still determination and clarity of approach can make the difference. Good governance is the key to national strength that leads to a strong national security policy.

Contrary to common perceptions about security, it is more elastic in nature. Security is not limited and confined to military security forces or agencies but it is comprised of all the institutions of civil and military structure. Concept of non-traditional security and human security as discussed in this paper do points to the fact that new and framework of security is required to counter emerging new threats in the international system. This new framework should be dynamic and responsive to the constantly changing dynamics of security system and should be complimented by the strength provided through good governance in the internal political system.

A clear and unambiguous national security strategy based on above outlined priorities is required. For good governance and effective economic development, a closer relationship between government, private sector and public should be built and strengthened for a responsive national security strategy. Complex threats faced by Pakistan today requires a close coordination of all key players of the national system.

Security, stabilization, democratization, constitutionality and good governance are the basic conditions needed for individual well-being, peaceful coexistence and social, political and economic development. new and appropriate measures should promote mechanisms providing peaceful solutions to conflicts and to provide protection and integration of minorities and underprivileged groups. For future of Pakistan, this is what guarantees national security.

After one decade of 9/11, situation for Pakistan is much more complex, fragile and requires immediate correction strategies in terms of revisiting national security and governance strategies. Pakistan is in such a complex security position that it cannot simply follow a traditional path that has led to such slow development. Pakistan is in a fragile security condition where the stakes are very high and it should prioritize its own national Security agenda to make sure it survives as a state.

\section{References}

Andrew, C., \& Goldsmith, M. (1998). From Local Government to Local Governance-and Beyond? International Political Science Review . available at: ips.sagepub.com/content/19/2/101 


\section{Macrothink}

Journal of Public Administration and Governance ISSN 2161-7104

Bislev, S. (2004). Globalization, State Transformation, and Public Security. International Political Science Review , 25 (3), 281-296. Available at: http://www.uk.sagepub.com/dicken6/Sociology\%20Online\%20readings/ch\%206\%20-\%20bis lev.pdf

Dryzek, J. (2006). Transnational Democracy in an Insecure World. International Political Science Review , 27 (2). doi: 10.1177/0192512106061421

Fung, A., \& Wright, E. O. (2001). Deepening Democracy: Innovations in Empowered Participatory Governance. Politics \& Society , 29 (1), 5-41. Available at: http://www.archonfung.com/papers/FungDeepDemocPS.pdf

Lindberg, S. (2001). Forms of States, Governance, and Regimes: Reconceptualizing the Prospects for Democratic Consolidation in Africa. International Political Science Review , 22 (2), 173-199.

Available

at: http://fmc90.files.wordpress.com/2010/11/statesgovernanceafrica.pdf

Moore, M. (2004). Revenues, State Formation, and the Quality of Governance in Developing Countries. International Political Science Review , 25 (3). Available at: http://www2.ids.ac.uk/gdr/cfs/pdfs/Moore\%20International\%20political\%20science\%20revie w\%20article\%202004.pdf

Paris, R. (2001). Human Security: Paradigm Shift or Hot Air. International Security, 26 (2), 87-102. Available at: http://aix1.uottawa.ca/ rparis/Paris.2001.IS.Human\%20Security.pdf

Tusicisny, A. (2007). Security Communities and Their Values: Taking Masses Seriously. International Political Science Review , 28 (4), 425-449. Available at: http://www.tusicisny.com/research/tusicisny_security_communities_and_their_values.pdf?84 $\operatorname{cd} 58$

Ziring, L. (2007). Pakistan in the Twentieth Century: A Political History. Karachi: Oxford University Press. 